\title{
Pendekatan Univariate Time Series Modelling untuk Prediksi Kuartalan Pertumbuhan Ekonomi Indonesia Pasca Vaksinasi COVID-19
}

\author{
Asrirawan $^{1^{*}}$, Sri Utami Permata ${ }^{2}$, Muhammad Ilham Fausan $^{3}$ \\ 1,3 Program Studi Statistika, Fakultas MIPA, Universitas Sulawesi Barat, Sulawesi Barat, Indonesia \\ ${ }^{2}$ Program Studi Manajemen, Fakultas Ekonomi, Universitas Sulawesi Barat, Sulawesi Barat, Indonesia \\ *Corresponding author. Email: asrirawan@unsulbar.ac.id
}

\begin{abstract}
ABSTRAK
Perkembangan COVID-19 memberikan dampak negatif yang cukup signifikan bagi pertumbuhan ekonomi Indonesia berdasarkan indikator nilai data kuartalan year of year tahun 2020 dan 2021. Pertumbuhan ekonomi masih mengalami resesi per kuartal pertama dengan persentase sebesar $-2,19 \%$ pada awal tahun 2021. Pemerintah telah mengambil tindakan vaksinasi untuk masyarakat secara bertahap yang bertujuan untuk menekan jumlah penderita kasus tersebut. Data deret waktu pertumbuhan ekonomi Indonesia sangat memungkinkan adanya pola tren turun dan musiman seiring berkembangnya kasus tersebut. Tujuan penelitian ini adalah untuk melakukan prediksi pertumbuhan ekonomi secara kuartalan pasca vaksinasi dengan menggunakan 3 (tiga) model univarite time series yakni model ARIMA, Holt-Winters dan Dynamic Linear dalam rangka pengambilan kebijakan sedini mungkin dalam penanganan kasus COVID-19. Di sisi lain, berdasarkan beberapa penelitian sebelumnya bahwa model Holt-Winters dan Dynamic Linear sangat memungkinkan untuk menangani data deret waktu yang mengandung tren dan musiman. Data deret waktu kuartalan pertumbuhan ekonomi Indonesia dibagi menjadi data latih dan data uji yang diperoleh dari kementerian keuangan dan Badan pusat Statistik Indonesia (BPS). Selanjutnya, data latih dimodelkan menggunakan ketiga model univariat tersebut yang menghasilkan hasil ramalan secara kuartalan kemudian dibandingkan dengan data uji untuk mendapatkan nilai MSE, MAE dan U-Theil sebagai evaluasi model. Proses analisis menggunakan bantuan $\mathrm{R}$ library yang menunjukkan bahwa pemodelan terbaik untuk data pertumbuhan ekonomi Indonesia pasca vaksinasi COVID-19 adalah model ARIMA $(1,0,0)$ dengan nilai MSE, MAE dan U-Theil terendah. Berdasarkan indikator U-Theil, selisih nilai error model ARIMA dan Holt-Winters sebesar 0,000242 sedangkan selisih model ARIMA dan Dynamic Linear sebesar 0,39923. Selain itu, model Holt-Winters dan Dynamic Linear menghasilkan ramalan pertumbuhan ekonomi Indonesia masih mengalami resesi (bertumbuh negatif) pada empat data kuartalan selanjutnya, sedangkan model ARIMA menghasilkan ramalan pertumbuhan positif pada kuartal keempat.
\end{abstract}

Kata Kunci:

Pertumbuhan Ekonomi; ARIMA; Holt-Winters; Dynamic Linear; R library

\section{ABSTRACT}

The development of COVID-19 has had a significant negative impact on Indonesia's economic growth based on the indicator of the value of the quarterly year of year data in 2020 and 2021. Economic growth is still experiencing a recession per first quarter with a percentage of - 2.19 percent at the beginning

e-ISSN: 2656-1344 (C) 2022 A. Asrirawan, S. U. Permata, M. I. Fausan | Under the license CC BY-NC 4.0 Received: 2 October 2021 | Accepted: 26 November 2021 | Online: 1 January 2022 
of 2021. The government has to take vaccination measures for the community gradually with the aim of reducing the number of sufferers of these cases. The purpose of this study is to predict economic growth quarterly after vaccination using 3 (three) univariate time series models, namely ARIMA, HoltWinters and Dynamic Linear models for policymaking. Holt-Winters and Dynamic Linear models make it possible to handle time-series data containing trends and seasonality. The data is divided into training data and test data obtained from the ministry of finance and the Indonesian Central Statistics Agency (BPS). The goodness of the model uses MSE, MAE and U-Theil criteria. Based on the results of the analysis using the $R$ library, the results show that the best modelling for economic growth data is the ARIMA model with the lowest MSE, MAE and U-Theil values with the difference between the models being 0.000242. The ARIMA model looks better than other models because the economic growth data only contains trends and assumes a seasonal element in the data. In addition, the Holt-Winters and Dynamic Linear models produce a forecast for Indonesia's economic growth to still experience a recession (negative growth) in the next four quarterly data, while the ARIMA model produces a positive growth forecast in the fourth quarter.

Keywords:

Economic Growth; ARIMA; Holt-Winters; Dynamic Linear; R library

Format Sitasi:

A. Asrirawan, S. U. Permata, and M. I. Fausan, "Pendekatan Univariate Time Series Modelling untuk Prediksi Kuartalan Pertumbuhan Ekonomi Indonesia Pasca Vaksinasi COVID-19", Jambura J. Math., vol. 4, No. 1, pp. 86-103, 2022, doi: https://doi.org/10.34312/jjom.v4i1.11717

\section{Pendahuluan}

Perhitungan Produk Domestik Bruto (PDB) pada tahun 2020 untuk mengukur pertumbuhan perekonomian Indonesia berdasarkan atas dasar harga telah menyentuh angka Rp. 15.434,23 triliun sedangkan untuk PDB per kapita berada pada angka Rp. 56,91 juta. Ekonomi nasional secara tak terduga berkontraksi (pertumbuhan negatif) 0,42\% qoq pada Q4 2020, kehilangan konsensus pasar dari pertumbuhan 0,72\% dan berbalik dari rekor ekspansi 5,05\% pada Triwulan ke-3. Di tengah pandemi COVID-19, dengan pemerintah kemudian memberlakukan pembatasan mobilitas di ibu kota Jakarta selama September dan Oktober 2020. Permintaan eksternal berkontribusi negatif terhadap PDB karena ekspor naik 2,41\% (vs 12,14 \% di Triwulan ke-3) sementara impor tumbuh jauh lebih cepat $16,28 \%$ (vs $-0,08 \%$ ) berdasarkan hasil perhitungan Badan Pusat Statistik (BPS) RI. Pada triwulan IV-2020, ekonomi nasional terjadi kontraksi pertumbuhan sebesar 0,42\% (q-toq) terhadap triwulan sebelumnya. Sebesar 20,15\%, bidang produksi Kehutanan, Lapangan Usaha Pertanian, dan Perikanan mengalami kontraksi pertumbuhan terdalam. Untuk sisi pengeluaran, komponen Pengeluaran Konsumsi Pemerintah (PK-P) mengalami pertumbuhan tertinggi dengan pertumbuhan sebesar 27,15\%. Pada 2020, Kelompok provinsi di pulau Jawa mendominasi struktur ekonomi Indonesia secara spasial sebesar 58,75\%, dengan kontraksi pertumbuhan berada pada angka 2,51\% [1].

Menurut Menteri Keuangan Sri Mulyani, salah satu harapan pemerintah untuk pemulihan ekonomi Indonesia adalah program vaksinasi yang dilakukan sejak Januari 2021 dalam rangka peningkatan mobilitas masyarakat seperti kegiatan ekspor, konsumsi dan investasi yang sangat berperan penting dalam pertumbuhan ekonomi nasional. Selain itu pemerintah telah menganggarkan biaya COVID-19 tahun 2021 sebesar Rp. 61,80 Triliun dan ini dinilai sudah cukup membebani biaya APBN serta ada kemungkinan terjadinya penambahan biaya anggaran dikarenakan jumlah pertambahan kasus COVID-19 yang cukup signifikan [2]. Sebagian besar nnggaran 


\section{A. Asrirawan, et.al}

biaya COVID-19 dialokasikan untuk program vaksinasi virus tersebut yang bertujuan untuk menekan laju pertumbuhan munculnya kasus baru.

Ada 4 (empat) tahapan program vaksinasi yang dilakukan oleh pemerintah dengan mempertimbangkan kedatangan, ketersediaan waktu, dan tahapan pelaksanaan vaksinasi. Tahapan tersebut meliputi (1) Tahap 1 dengan sasaran asisten tenaga kesehatan, mahasiswa profesi kedokteran dan tenaga kesehatan yang rencananya akan direalisasikan pada Januari-April 2021. (2) Tahap 2 dengan sasaran Petugas pelayanan publik yaitu aparat hukum, TNI/Polri Indonesia, petugas pelayanan publik (pelabuhan terminal/bandara/stasiun), PLN, dan PDAM, serta petugas pelayanan masyarakat, Kelompok usia lanjut dengan rencana realisasi Januari-April 2021. (3) Tahap 3 dengan sasaran masyarakat rentan dari aspek sosial, geospasial dan ekonomi dan waktu rencana realisasi April 2021-Maret 2022. (4) Tahap 4 dengan sasaran pelaku perekonomian lainnya dan masyarakat dengan pendekatan kluster sesuai dengan ketersediaan vaksin dan waktu rencana realisasi April 2021-Maret 2022 [3].

Prediksi pertumbuhan ekonomi sangat esensial dalam penentuan kebijakan ekonomi negara. Model prediksi yang cukup banyak digunakan adalah model ekonometrik deret waktu (time series econometric) yang telah tebukti menjadi alat yang efektif untuk memahami pola perilaku kumpulan data yang memiliki pola urutan dari waktu ke waktu, dengan berbagai model untuk tujuan menganalisis dan memprediksi data-data yang memiliki variasi trend dan musiman seperti data pertumbuhan ekonomi, PDB, saham, dan lain-lain. Beberapa peneliti di dunia telah memprediksi pertumbuhan ekonomi secara kuartalan baik model univariat maupun multivariat seperti model ARIMA, Holt-Winters dan Dynamic Linear. Seasonal Autoregressive Integrated Moving average (SARIMA) dan model Holt-Winters dianggap sebagai model deret waktu klasik dan kelas model linier dinamis merupakan bagian dari pendekatan Bayesian. Berkaitan dengan kontribusi yang menggunakan model klasik, analisis dibangun oleh Abonazel dan Abd-Elftah [4] untuk PDB tahunan Mesir antara tahun 1965 dan 2016, dengan prakiraan sepuluh tahun ke depan (2017 s.d 2026), serta menyajikan hasil yang menunjukkan pertumbuhan PDB Negara selama periode yang dianalisis untuk pendekatan Bayesian dan kelas model ruang-negara. Model yang digunakan untuk memprediksi adalah model ARIMA $(1,2,1)$ berdasarkan nilai minimun AIC, BIC dan MSE dari 7 (tujuh) model yang diidentifikasi. Piccoli [5] menganalisis empat model linier dinamis untuk mengidentifikasi model pertumbuhan ekonomi dengan kapasitas peramalan terbaik untuk PDB nominal di Amerika Serikat.

Perbedaan pola pergerakan pertumbuhan ekonomi setiap negara memungkinkan berbeda-beda, sehingga kemungkinan model yang tepat untuk digunakan memprediksi atau meramalkan kasus tersebut juga akan berbeda-beda. Tujuan utama dari penelitian ini adalah untuk mendapatkan model yang tepat untuk peramalan data deret waktu pertumbuhan ekonomi Indonesia dalam periode kuartalan yang memiliki serta membandingkan tiga model yang dipilih yakni model ARIMA, Holt-Winters dan Dynamic Linear. Sebelumnya, beberapa penelitian yang dijelaskan tidak membandingkan ketiga model tersebut yang memiliki keunggulan masing-masing dalam memprediksi. Selain itu, pemodelan ini menggunakan bantuan statistical software $R$ Library. Beberapa kriteria untuk membandingkan ketiga model tersbut juga disajikan dalam penelitian ini seperti nilai MSE, MAE dan U-Theil. 


\section{Metode}

\subsection{Analisis Deret Waktu}

Analisis deret waktu merupakan salah satu analisis statistik yang menggunakan pola data runtuan waktu, dengan asumsi bahwa deret waktu tersebut saling berkorelasi atau dependen seperti data harian penjualan, curah hujan, penyakit pandemi dan lain-lain. Data deret waktu mempunyai pengukuran waktu diskrit karena pengamatannya menggunakan interval waktu. Tujuan dari analisis deret waktu adalah untuk melihat pola pergerakan dari waktu ke waktu dari sebuah kejadian, untuk mengontrol sebuah sistem, dan untuk meramalkan dan memprediksi kejadian pada waktu yang akan datang. Akan tetapi, tujuan utama menggunakan analisis deret waktu adalah untuk mendapatkan dan melihat hubungan antara $Y_{t}$ dengan $Y_{t-1}, Y_{t-2}, \ldots$ dimana $Y_{t}$ merupakan pengamatan $Y$ pada waktu ke-t dan $Y_{t-1}, Y_{t-2}, \ldots$ merupakan pengamatan $Y$ pada waktu-waktu sebelumnya yakni $(t-1, t-2$, dan seterusnya) [6]. Model deret waktu telah banyak dikembangkan baik model univariat maupun model multivariat. Model univariat seperti Holt-Winters, ARIMA dan Dynamic Linear merupakan beberapa model deret waktu yang bisa menangani data deret waktu yang mengandung unsur musiman dan tren pada data.

\subsection{Model ARIMA}

Model ARIMA adalah model deret waktu yang bersifat linear dan melibatkan komponen Autoregressive (AR), model moving average (MA) dan unsur ketidak stasioneran data. Model yang melibatkan ketidakstasioneran data deret waktu yang mengandung orde AR dan MA dapat dilihat dengan jelas pada penelitian Qadrini, et al [6] dan Asrirawan, et al [7]. Untuk mengatasi adanya pola musiman pada data maka Model ARIMA dikembangkan menjadi model Seasonal (musiman) ARIMA dimana pada waktu-waktu tertentu memiliki pola tersendiri pada lag-lag 12, 24, 36 dan seterusnya. Pemodelan ARIMA sangat tepat dan akurat untuk meramlkan data dalam jangka pendek sedangkan untuk peramalan data-data jangka panjang kurang baik digunakan dikarenakan nilainya yang tidak fluaktuatif dan flat atau cenderung konstan. Adapun prosedur pemodelan ARIMA box jenkins ini terdiri atas empat tahapan yakni tahap identifikasi model, tahap estimasi parameter, tahap diagnostic check dan tahap peramalan atau prediksi.

Diberikan $y_{t}$ adalah barisan deret waktu $\left\{y_{1}, y_{2}, \ldots, y_{t}\right\}$, persamaan model ARIMA $(p, d, q)$ seperti pada persamaan (1) [7].

$$
\phi_{p}(B)(1-B)^{d} y_{t}=\theta_{q}(B) a_{t}
$$

dengan $a_{t} \sim W N\left(0, \sigma^{2}\right), p$ orde $\mathrm{AR}, q$ orde MA, $d$ orde pembeda, $\phi_{p}(B)$ dapat dijabarkan dengan barisan suku $1-\phi_{1} B-\phi_{2} B^{2}-\ldots-\phi_{p} B^{p}$, sedangkan $\theta_{q}(B)$ dapat ditulis $1-\theta_{1} B-\theta_{2} B^{2}-\ldots-\theta_{q} B^{q}$ penentuan komponen orde $p$ dan $q$ yang dapat dilihat dari cut off lag masing-masing plot ACF dan PACF. Langkah-langkah pemodelan ARIMA menggunakan ARIMA Box-Jenkins sebagai berikut:

\subsubsection{Tahap Identifikasi}

Pada tahap ini, data diuji apakah data stasioner dalam rata-rata dan variansi. Time series plot, ACF dan PACF serta Uji Augmented Dickey-Fuller (ADF) dapat digunakan untuk 


\section{A. Asrirawan, et.al}

melihat kestationeran data. Data yang tidak stasioner rata-rata dan variansi dilakukan proses differencing dan transformasi. Untuk melihat plot-plot di atas, library t-series, forecast dan FitAR pada aplikasi $\mathrm{R}$ dapat diterapkan. Selain itu, tahap ini juga digunakan untuk mendapatkan orde $p, d$, dan $q$ pada model ARIMA dengan melihat plot ACF dan PACF.

\subsubsection{Tahap Estimasi Parameter}

Model-model dugaan awal pada tahap sebelumhya digunakan untuk mengestimasi parameter pada persamaan (1). Parameter yang signifikan apabila mempunyai nilai $p$ - value atau signifikansi dibawah 0,05. Model yang memenuhi signifikansi kemudian dilanjutkan ke tahap pengecekan diagnostic.

\subsubsection{Tahap Diagnostic Check}

Untuk model-model yang telah memenuhi signifikansi parameter, proses selanjutnya adalah pengecekan asumsi white noise. Pengecekan asumsi white noise dengan memperhatikan lag-lag residual model serta menggunakan Uji Ljung-Box dan $Q-Q$ Plot dengan nilai $p$-value di atas 0,05 .

\subsubsection{Tahap Ramalan}

Model yang digunakan untuk tahap peramalan adalah model yang telah memenuhi tahapan sebelumnya. Hasil ramalan dari tiap model dibandingkan dengan menggunakan error terkecil antara nilai ramalan tersebut dengan data aktual.

\subsection{Model Seasonal ARIMA}

Pada bagian sebelumnya, diberikan deret waktu $y_{t}$ mengikuti model ARIMA $(p, d, q)$ yang dapat dituliskan secara matematis pada persamaan (1). Model ARIMA juga dapat diterapkan pada data yang memiliki pola musiman yang dirumuskan seperti pada persamaan (2). Kombinasi persamaan (1) dengan persamaan (2) akan menghasilkan model multiplikatif seasonal ARIMA (SARIMA) pada persamaan (3).

$$
\begin{gathered}
\Phi_{P}(B)(1-B)^{D} y_{t}=\Theta_{Q}(B) a_{t} \\
\phi_{p}(B) \Phi_{P}(B)(1-B)^{d}(1-B)^{D} y_{t}=\theta_{q}(B) \Theta_{Q}(B) a_{t}
\end{gathered}
$$

dimana:

$P$ : komponen dari musiman autoregressive (AR)

$D$ : komponen dari musiman differencing

$Q$ : komponen dari musiman moving average (MA)

$S:$ musiman (seasonal)

$$
\begin{aligned}
& \phi_{P}\left(B^{S}\right)=1-\phi_{1} B^{S}-\phi_{2} B^{2 S}-\ldots-\phi_{p} B^{P S} \\
& \theta_{Q}\left(B^{S}\right)=1-\theta_{1} B^{S}-\theta_{2} B^{2 S}-\ldots-\theta_{P} B^{Q S}
\end{aligned}
$$

\subsection{Model Holt-Winters}

Seperti yang dijelaskan dalam Al-Turaiki, et al [8], metode Holt-Winters telah diusulkan oleh Holt [9] dan Nurhamidah [10], menggunakan rata-rata bergerak tertimbang 
eksponensial yang diperlukan untuk penyesuaian musiman rata-rata (trend) dan musiman. Metode ini memiliki dua variasi dengan empat persamaan: satu persamaan prakiraan dan tiga persamaan smoothing. Hyndman dan Athanasopoulos [11] menjelaskan bahwa hal itu terdapat dalam model aditif dimana komponen musiman didefinisikan sebagai nilai absolut pada skala yang diamati secara seri. Dalam persamaan level, persamaan deret waktu ke- $t$ dikurangi dengan komponen musiman ke $t-m$. Dalam setiap tahun, jumlah komponen musiman mendekati nol. Dengan metode perkalian, komponen musiman didefinisikan dalam persentase dan rangkaian tersebut diasumsikan secara musiman dengan membaginya dengan komponen musiman $m$ sehingga komponen musiman akan berjumlah kira-kira $m$.

Persamaan metode aditif diperjelas pada persamaan (4) sebagai berikut:

$$
\begin{aligned}
\hat{y}_{t+h} & =\ell_{t}+h b_{1}+s_{t+b-m(k-1)} \\
\ell_{t} & =\alpha\left(y_{t}-s_{t-m}\right)+(1-\alpha)\left(\ell_{t-1}+b_{t-1}\right) \\
b_{t} & =\beta\left(\ell_{t}-\ell_{t-1}\right)+(1-\beta) b_{t-1} \\
s_{t} & =\gamma\left(y_{t}-\ell_{t-1}\right)+(1-\gamma) s_{t-m}
\end{aligned}
$$

dimana $\hat{y}_{y+h}$ adalah persamaan ramalan atau prediksi. Sedangkan $\ell_{t}, b_{t}$ dan $s_{t}$ masing-masing adalah level, trend dan persamaan musiman, dengan parameter penghalusan yang sesuai $a, \beta$ dan $\gamma$. Selain itu, $m$ menunjukkan frekuensi musim, dan untuk data kuartalan $m=4$. Terakhir, $k$ adalah bagian bilangan bulat dari $\left(\frac{(h-1)}{m}\right)$ yang memastikan bahwa estimasi indeks musiman digunakan untuk peramalan berasal dari tahun terakhir sampel. Untuk metode perkalian, persamaan $\ell_{t}, b_{t}$ dan $s_{t}$ didefinisikan, tetapi perubahan struktur terjadi karena alih-alih menjumlahkan persamaan dalam sebuah operasi adalah dilakukan untuk mengalikan jumlah persamaan level dan trend dengan persamaan musiman.

\subsection{Model Dynamic Linear}

Model linear dinamis adalah salah satu model state space yang banyak digunakan di dekade terakhir ini. Model tersebut memiliki tingkat efisiensi yang tinggi untuk analisis dan ramalan waktu seri dan memberikan fleksibilitas serta penerapan konsep probabilitas yang cukup rumit. Prosedur dan tahapan estimasi dan inferensi didekati dengan menggunakan algoritma rekursif pada prinsip pendekatan Bayesian dan menghitung distribusi bersyarat dari deret waktu yang diamati. Mengingat model yang dibentuk dipengaruhi oleh waktu, melalui proses dinamika dan deformasi acak, maka model tersebut dihubungkan dengan komponen musiman atau regresif.

Model dynamic linear telah dibahas oleh Laine [12] dan Petris [13]. Untuk setiap waktu $t$, DLM univariat umum didefinisikan oleh persamaan observasi (5).

$$
Y_{t}=F_{t} x_{t}+v_{t}, v_{t} \sim N_{m}\left(0, V_{t}\right)
$$

dengan sistem persamaan (6)

$$
x_{t}=G_{t} x_{t-1}+\omega_{t}, \omega_{t} \sim N_{m}\left(0, W_{t}\right)
$$




\section{A. Asrirawan, et.al}

dan misal informasi yang diberikan adalah

$$
\left(x_{0} \mid D_{0}\right) \sim N\left(m_{0}, C_{0}\right)
$$

dimana $\mathrm{F}_{t}$ dan $\mathrm{G}_{t}$ adalah matriks yang diketahui, sedangkan $\mathrm{w}_{t}$ dan $\mathrm{v}_{t}$ adalah dua deret dan noise yang bebas dengan rata-rata sama dengan nol serta masing-masing kovariansnya adalah $\mathrm{W}_{t}$ dan $\mathrm{V}_{t} . \mathrm{D}_{t}$ adalah barisan waktu atau informasi sekarang yang diamati dimana $\mathrm{D}_{t}$ cukup $\left(Y_{t+1}, x_{t+1}, \cdots Y_{t+k}, x_{t+k}\right)$ sedangkan untuk menentukan trend dan musim itu ditentukan oleh $x_{t}=\left(u_{t}, \beta_{t}, \gamma_{t}, \gamma_{t-1}, \gamma_{t-2}\right)$ dimana $u_{t}$ adalah tingkat pada saat ini, $\beta_{t}$ adalah tingkat kemiringan dari trend sedangkan $\gamma_{t}, \gamma_{t-1}, \gamma_{t-2}$ adalah periode musiman. Selain itu, proses Kalman filtering, penghalusan Kalman Filtering, estimasi parameter dan prediksi data akan disajikan pada bagian ini. Tiga komponen utama luaran yang akan ditunjukkan pada model dynamic linear sebagai berikut:

1. $a$ adalah peramalan state space untuk satu tahapan ke depan dengan menggunakan persamaan (7).

$$
a_{t}=G_{t} m_{t-1}
$$

dimana

$$
x_{t} \mid y_{t-1} \sim N\left(a_{t}, R_{t}\right)
$$

dan

$$
R_{t}=G_{t} C_{t-1} G_{t}^{T}+W_{t}
$$

2. $f$ adalah nilai peramalan observasi beberapa tahapan kedepan dengan menggunakan persamaan (8).

$$
f_{t}=F_{t} a_{t}
$$

dimana

$$
y_{t} \mid y_{t-1} \sim N\left(f_{t}, Q_{t}\right)
$$

dan

$$
Q_{t}=F_{t} R_{t-1} F_{t}^{T}+V_{t}
$$

3. $m$ adalah nilai posterior dengan menggunakan persamaan (9)

$$
m_{t}=R_{t} f_{t} Q_{t}^{-1}\left(y_{t}-f_{t}\right)
$$

dan

$$
C_{t}=R_{t}-R_{t} F_{t}^{T} Q_{t}^{-1} F_{t} R_{t}
$$

Pemodelan dengan tahap seperti ini memungkinkan untuk membuat plot tren linier tanpa mengetahui terlebih dahulu komponen musiman.

\subsection{Kriteria Pemilihan Model Terbaik}

Pemilihan model peramalan yang paling sesuai dilakukan melalui perhitungan dari persamaan Hyndman dan Koehler [14], Silitonga, et.al [15] dan Lee [16] dengan menggunakan nilai metrik berikut:

\subsubsection{Root Mean Squared Error (RMSE)}

RMSE digunakan untuk menghitung nilai galat antara nilai prediksi yang diperoleh dari hasil model dengan nilai aktual kemudian diakarkan. Persamaan (10) adalah 
rumus untuk menghitung nilai RMSE.

$$
R M S E=\frac{\sum_{t=1}^{n} \sqrt{\hat{y}_{t}-y_{t}}}{n}
$$

\subsubsection{Mean Absolut Error (MAE)}

MAE digunakan untuk menghitung nilai galat antara nilai prediksi yang diperoleh dari hasil model dengan nilai aktual kemudian absolutkan. Persamaan (11) adalah rumus untuk menghitung nilai MAE.

$$
M A E=\frac{\sum_{t=1}^{n}\left|\hat{y}_{t}-y_{t}\right|}{n}
$$

\subsubsection{Mean Absolut Percentage Error (MAPE)}

MAPE digunakan untuk menghitung nilai galat prediksi model yang dinyatakan dengan persentase rata-rata absolute galat. Persamaan (12) adalah rumus untuk menghitung nilai MAPE.

$$
M A P E=100 \times \frac{\sum_{t=1}^{n}\left|\frac{\hat{y}_{t}-y_{t}}{y_{t}}\right|}{n}
$$

\subsubsection{Theil's Koefisien Ketimpangan (U-Theil)}

Koefisien U-Theil adalah salah satu ukuran akurasi model ramalan yang membandingkan antara data aktual dengan data hasil ramalan yang dapat mengatasi jumlah ramalan yang sedikit. Perhitungan nilai koefisien U-Theil merujuk pada persamaan (13).

$$
U-\text { Theil }=\sqrt{\frac{\sum_{t=1}^{n+1}\left(\frac{\hat{y}_{t+1}-y_{t+1}}{y_{t}}\right)^{2}}{\sum_{t=1}^{n+1}\left(\frac{\hat{y}_{t+1}-y_{1}}{y_{t}}\right)^{2}}}
$$

\subsection{Pertumbuhan Ekonomi}

Produk Domestik Bruto (PDB) atau Gross Domestic Product (GDP) adalah nilai barang dan jasa yang dihasilkan oleh suatu negara pada kurun waktu tertentu. PDB ini menjadi indikator dalam perumusan pertumbuhan ekonomi suatu negara. GDP ini dihitung berdasarkan input atau produk dari warga negara atau warga negara asing yang telah diatur oleh negara baik produk jasa maupun barang [17]. Manfaat dari perhitungan PDB adalah sebagai berikut [18]: (1) Untuk mengetahui bagaimana tingkat produktivitas Negara; (2) Untuk mengetahui bagaimana tingkat kesejahteraan sosial masyarakat; (3) Untuk mengetahui bagaimana tingkat kemakmuran Negara.

Variabel yang paling dominan dalam menentukan nilai komponen pendapatan negara adalah asumsi pertumbuhan ekonomi. Pertumbuhan ekonomi adalah indikator dasar ekonomi makro nasional yang secara signifikan berhubungan positif langsung dengan penerimaan atau pendapatan suatu negara baik pendapatan pajak dalam negeri seperti 


\section{A. Asrirawan, et.al}

Pajak Pertambahan Nilai, Pajak Penghasilan, Cukai, Pajak Bumi dan Bangunan (PBB) dan Pajak lainnya maupun pendapatan Negara Bukan Pajak seperti laba BUMN). Untuk menghitung pertumbuhan ekonomi digunakan rumus seperti persamaan (14):

$$
P E=\left(\frac{P D B_{T}-P D B_{T-1}}{P D B_{T-1}}\right) \times 100 \%
$$

dengan $P E$ adalah Pertumbuhan ekonomi, $T$ adalah waktu tertentu dan $T-1$ adalah waktu periode sebelumnya, $\mathrm{PDB}_{T}$ adalah Produk Domestik Bruto (PDB) pada tahun ke-t. Perhitungan $P E$ tersebut dilakukan secara kuartalan sehingga setiap tahun diperoleh empat data nilai pertumbuhan ekonomi.

\subsection{Data}

Data yang digunakan dalam penelitian ini adalah data primer dan sekunder yang diperoleh dari Kementrian Keuangan dan Badan Pusat Statistik Nasional tentang data harian, bulanan, dan kuartalan pertumbuhan ekonomi Indonesia dari sebelum vaksinasi COVID-19 (Maret 2001) dan data setelah vaksinasi COVID-19 tahap pertama Januari-April 2021 dengan jumlah data sebanyak 81 data observasi. Data dibagi menjadi data latih dan data uji. Data latih yang digunakan mulai dari Maret 2001-Maret 2020 (kuartalan) sedangkan data uji yang digunakan yakni Juni 2020-Maret 2021. Selanjutnya, data latih digunakan untuk membangun model ARIMA, Holt-Winters, Dynamic Linear, hasil ramalan data latih dibandingkan dengan data uji untuk mendapatkan nilai MSE, MAE dan U-Theil.

\section{Hasil dan Pembahasan}

Bagian ini akan membahas terkait deskripsi data, langkah-langkah pemodelan, hasil analisis pemodelan, evaluasi model dan hasil ramalan menggunakan model ARIMA, Holt-Winters dan Dynamic Linear. Proses membangun ketiga model tersebut menggunakan bantuan aplikasi $R$ software ( $R$ library) yang telah tersedia di $R$ package dan beberapa syntax tambahan.

\subsection{Deskripsi Pertumbuhan Ekonomi Indonesia}

Untuk memudahkan interpretasi data pertumbuhan ekonomi Indonesia, data tersebut dibuat dalam bentuk time series plot dengan simbol data deret waktu $y_{t}$ dimana $t=1,2,3, \ldots, 81$. Grafik time series menggunakan $R$ package (library ggplot 2 ) dapat dilihat pada Gambar 1. Misalkan, file data pertumbuhan disimpan dalam direktori "C:/Users/ADAM/Downloads/Pertumbuhan Ekonomi Kuartalan.xlsx", maka penginputan data di $R$ dapat dilakukan dengan menggunakan sintaks berikut.

$>\operatorname{library}($ ggplot2)

$>$ Pertumbuhan_Ekonomi_Kuartalan<-read_excel("C:/Users/ADAM/Downloads/Pertumbuhan Ekonomi Kuartalan.xlsx")

$>\operatorname{ggplot}(g d p$, aes $($ Waktu, Growth) $)+$ geom_line( $)+x l a b(" W a k t u$ Kuartalan") + ylab("Growth")

Pertumbuhan ekonomi Indonesia terlihat mengalami kenaikan dan penurunan (fluktuatif) pada tahun 2001 hingga tahun 2019 berdasarkan Gambar 1. Selain itu, pada tahun-tahun tersebut, Indonesia mengalami pertumbuhan ekonomi yang positif antara $1 \%-8 \%$. Sebaliknya pada tahun 2020, pertumbuhan ekonomi indonesia menunjukkan 
terjadinya resesi atau adanya kemunduran ekonomi yang ditandai dengan pertumbuhan ekonomi yang negatif. Tingkat resesi ekonomi tertinggi berada pada waktu kuartalan di Juni 2020. Terjadinya resesi tersebut disebabkan oleh adanya lonjakan kasus COVID-19 sejak munculnya pandemi ini di akhir tahun 2019. Peningkatan jumlah kasus COVID-19 memaksa pemerintah untuk mengeluarkan kebijakan yang membatasi pergerakan masyarakat seperti PSBB dan PPKM. PSBB dan PPKM mengakibatkan terjadinya penurunan mobilisasi masyarakat yang cukup signifikan sehingga hal tersebut juga mengakibatkan menurunnya nilai PDB yang berdampak pada pertumbuhan ekonomi Indonesia. Namun, terlihat pada kuartal I di tahun 2021, pertumbuhan ekonomi mengalami peningkatan yang cukup signifikan meskipun masih berada pada kondisi resesi dari $-2,19 \%$ menuju $-0,74 \%$. Hal ini mengindikasikan adanya pengaruh dari program vaksinasi dari pemerintah pada tahap pertama yang menyebabkan terjadinya penurunan jumlah kasus COVID-19 harian dan terjadinya pelonggaran pembatasan kegiatan masyarakat khususnya yang telah melakukan vaksinasi.

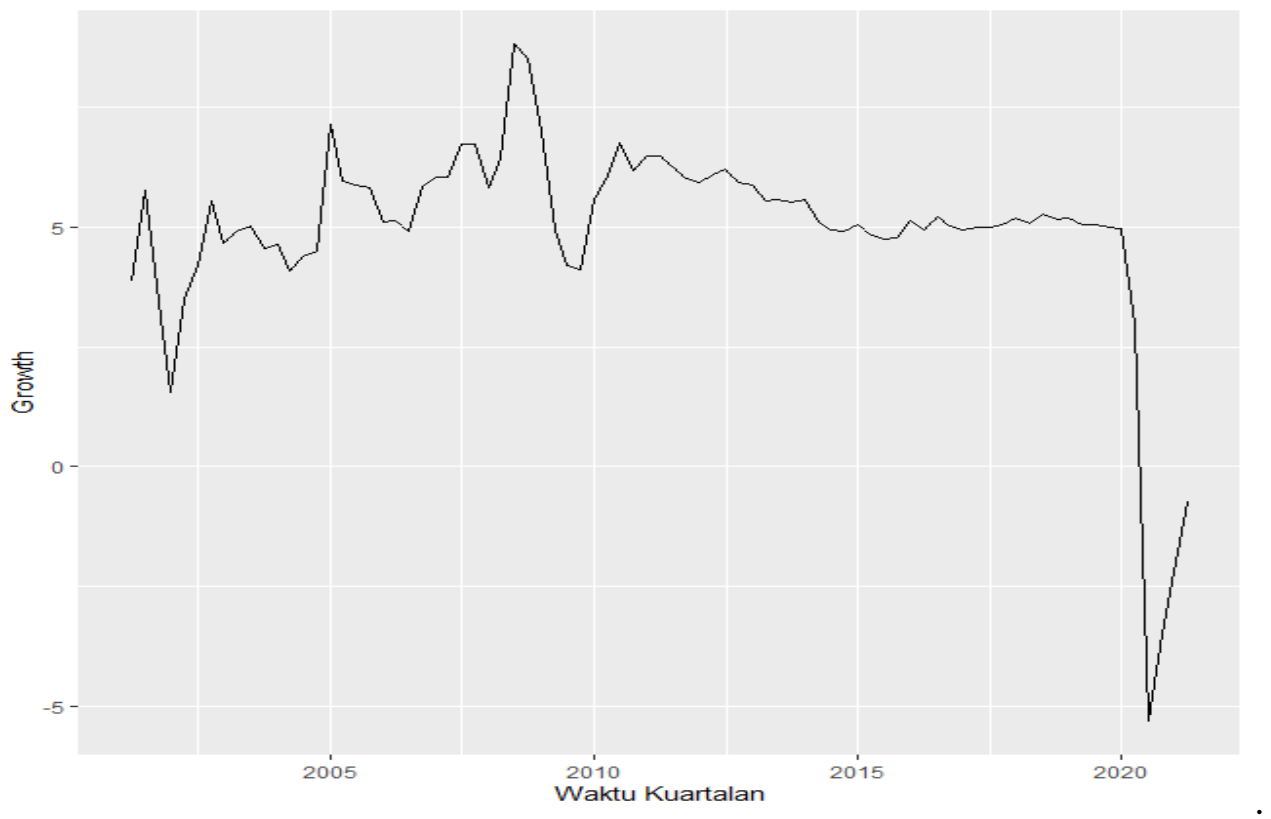

Gambar 1. Data pertumbuhan ekonomi Indonesia kuartalan (2001-2020)

\subsection{Model ARIMA Pertumbuhan Ekonomi Indonesia}

Pemodelan ARIMA dimulai dari identifikasi stasioneritas rerata dan variansi serta model dugaan sementara, estimasi parameter, uji asumsi dan tahap peramalan. Tahap pertama terkait identifikasi stasioneritas dapat dilihat pada Gambar 1. Gambar 1 menunjukkan bahwa data belum stasioner dalam variansi karena terjadi perubahan variansi dari waktu ke waktu (konstan). Untuk melihat stasioneritas rerata dapat dilakukan dengan menggunakan Uji Augmented Dickey-Fuller (ADF) pada data latih.

$>$ library(tseries)

$>$ adf.test (gdp_growth_ts)

$>$ dif_growth $<-$ diff(gdp_growth_ts, differences=1) 


\section{A. Asrirawan, et.al}

Hasil dari olah data di $R$ menggunakanlibrary tseries menunjukkan nilai $P$ - value sebesar 0,9731 . Artinya, data belum memenuhi stasioneritas rerata sehingga data latih tersebut perlu di lakukan differencing. Dari hasil differencing pada lag 1 diperoleh nilai $P$ - value pada uji ADF sebesar 0,01 sehingga data telah stasioner dalam rerata. Selain itu, hasil ACF dan PACF dari data differencing pada lag 1 dapat dilihat pada Gambar 2 yang menunjukkan bahwa data telah stasioner. Hal ini disebabkan karena terjadi penurunan pada lag-lag yang cukup signifikan atau cut off pada lag 1 seperti yang terlihat pada plot ACF.
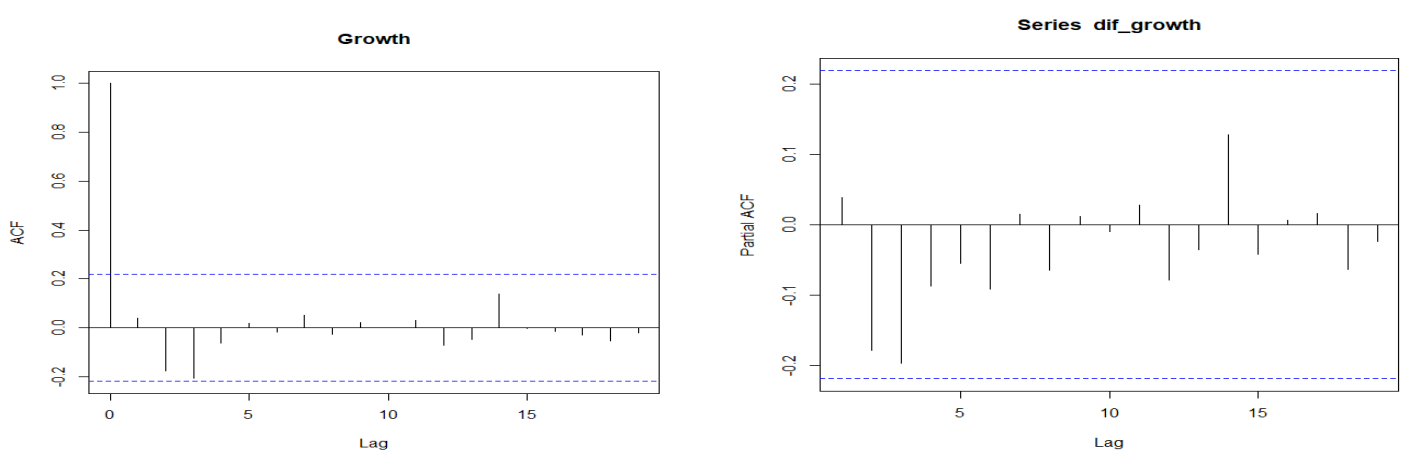

Gambar 2. Plot ACF dan PACF data differencing pada lag 1

Plot ACF menunjukkan bahwa hanya lag 1 yang signifikan (cut of lag 1) dan lag-lag yang memiliki nilai autokorelasi yang cukup tinggi adalah lag 3 dan lag 4 sedangkan pada PACF terdapat lag yang cukup tinggi yaitu lag 1, lag 2, dan lag 3. Artinya, identifikasi model awal dan estimasi parameter pada data latih dapat dilihat pada Tabel 1.

Tabel 1. Estimasi parameter model seleksi ARIMA pada data latih dengan taraf kepercayaan $95 \%$

\begin{tabular}{ccccccc}
\hline Model & Parameter & Estimasi & Std. Error & P-Value & Keterangan & NilaiAIC \\
\hline ARIMA (1,1,1) & $\phi_{1}$ & $-0,78157$ & 0,38250 & 0,04102 & Signifikan & 270,51 \\
& $\theta_{1}$ & 0,84556 & 0,34050 & 0,01302 & Signifikan & \\
ARIMA (1,0,0) & $\phi_{1}$ & 0,841167 & 0,064729 & 0,00001 & Signifikan & 269,98 \\
ARIMA (0,0,1) & $\theta_{1}$ & 0,77364 & 0,06684 & 0,00001 & Signifikan & 297,78 \\
ARIMA (0,0,2) & $\theta_{1}$ & 0,95825 & 0,10888 & 0,00001 & Signifikan & 281,98 \\
& $\theta_{2}$ & 0,50317 & 0,10246 & 0,00001 & Signifikan & \\
ARIMA (0,0,3) & $\theta_{1}$ & 0,93628 & 0,11119 & 0,00001 & Signifikan & 274,77 \\
& $\theta_{2}$ & 0,65783 & 0,11753 & 0,00001 & Signifikan & \\
& $\theta_{3}$ & 0,45340 & 0,13651 & 0,00001 & Signifikan & \\
\hline
\end{tabular}

Beberapa model tidak ditampilkan pada tabel karena tidak memenuhi nilai signifikansi parameter. Model yang digunakan mengkombinasikan model dengan menggunakan orde pembeda pada lag 1 dan tanpa menggunakan orde pembeda. Selain itu, adanya unsur musiman pada data juga tidak ditampilkan pada model dugaan sementara karena parameter model tidak signifikan. Unsur musiman pada data ditandai dengan nilai laglag 12, 24 yang cukup signifikan pada plot ACF dan PACF.

$>$ library(fUnitRoots)

$>$ fitARIMA $<-$ arima $\left(g d p_{-}\right.$growth_ts, order $=c(1,0,0)$, method=" $\left.M L "\right)$

Selanjutnya untuk melihat hasil estimasi paramter menggunakan paket fUnitRoots pada 
$R$ telah disajikan pada Tabel 1. Hasil estimasi parameter untuk model yang diseleksi menunjukkan bahwa semua parameter telah memenuhi signifikansi dengan menggunakan taraf kepercayaan sebesar $95 \%$.

Dengan menggunakan nilai Akaike Information Criteria (AIC) sebagai kriteria kebaikan model pada data latih maka diperoleh bahwa model ARIMA $(1,0,0)$ adalah model terbaik untuk meramalkan atau memprediksi nilai pertumbuhan ekonomi dengan nilai AIC sebesar 269,98. Selanjutnya pengujian asumsi residual white noise dan asumsi normalitas dilakukan dengan menggunakan uji Ljung Box dan menggunakan Q-Q Plot ( $R$ library FitAR). Hasil olah data $R$ diperoleh bahwa model ARIMA $(1,0,0)$ telah memenuhi kedua asumsi tersebut. Nilai signifikansi dari setiap lag pada uji Ljung Box dan Q-Q Plot berada di atas nilai 0,05 sehingga dapat disimpulkan bahwa asumsi white noise dan uji normalitas telah terpenuhi. Tahap selanjutnya adalah prediksi data kuartalan dengan menggunakan library forecast yang dapat dilihat hasilnya pada Gambar 3.

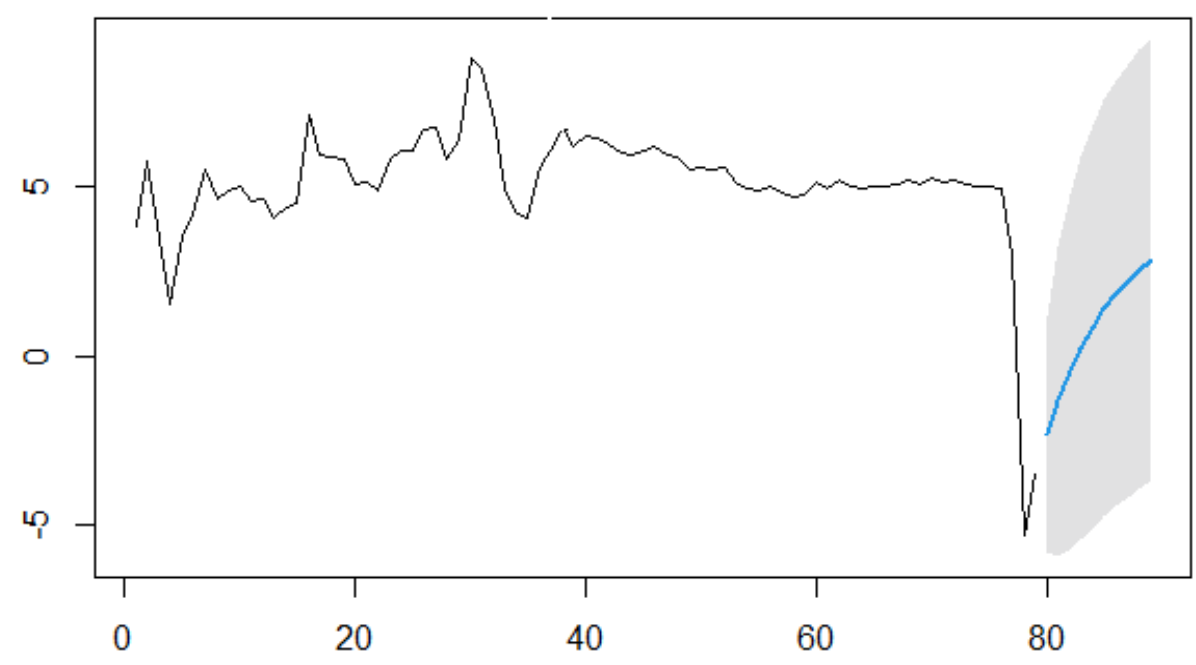

Gambar 3. Prediksi empat data Kuartalan dari Model ARIMA $(1,0,0)$

Gambar 3 menunjukkan nilai ramalan pertumbuhan ekonomi dengan menggunakan model ARIMA $(1,0,0)$ (garis biru) dan daerah batas atas dan batas bawah nilai ramalan. Berdasarkan gambar tersebut, hasil peramalan menunjukkan bahwa pertumbuhan ekonomi Indonesia mengalami peningkatan hingga di kuartal ketiga pasca vaksinansi tahap pertama meskipun masih terjadi resesi atau titik-titik ramalan berada di sekitaran sumbu negatif. Adapun hasil peramalan di kuartal ke empat terlihat bahwa pertumbuhan ekonomi Indonesia sudah tidak terjadi resesi atau titik ramalan berada di sekitaran sumbu positif.

\subsection{Model Holt-Winters Pertumbuhan Ekonomi Indonesia}

Data pertumbuhan ekonomi menunjukkan adanya tren turun selama kuartalan di tahun 2020 kemudian mengalami kenaikan di akhir kuartal 2020 seperti yang terlihat pada Gambar 1. Untuk mengatasi unsur tren dan pola musiman pada data maka digunakan model Holt-Winters. Pola dari trend dan musiman dapat dilihat pada Gambar 4.

Pada Gambar 4 terlihat bahwa adanya tren pada data dikarenakan grafik tren cenderung tidak stabil dibeberapa deret waktu khususnya di kuartal akhir 2020 dan 


\section{A. Asrirawan, et.al}

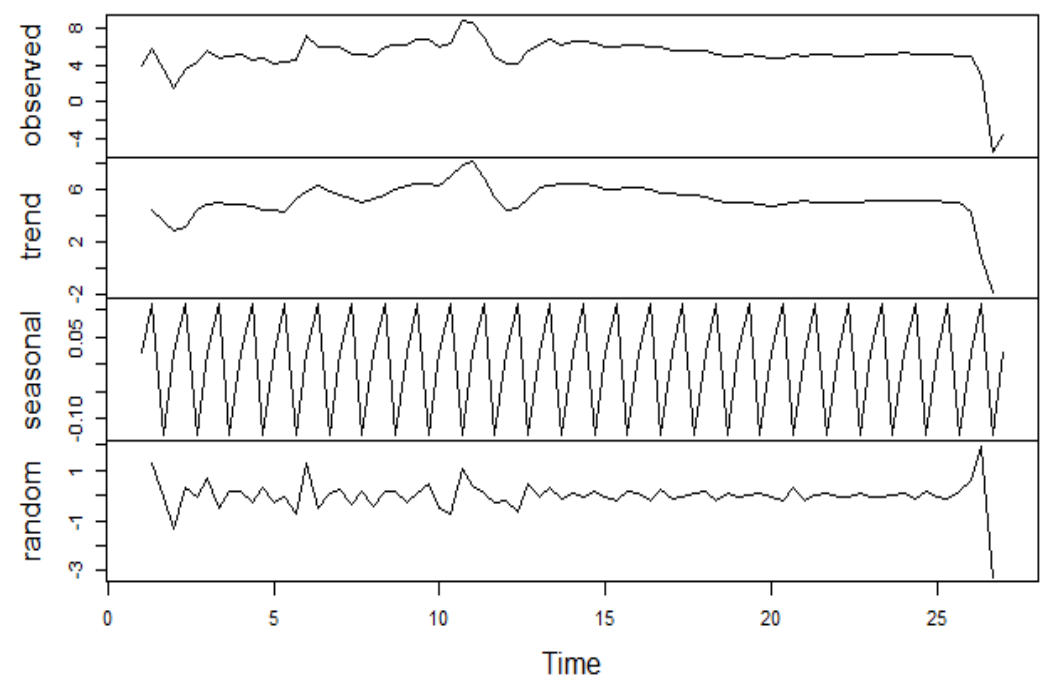

Gambar 4. Komponen tren dan musiman pada data pertumbuhan ekonomi Indonesia

turun (tren negatif) secara signfikan. Selain itu, grafik musiman pada gambar tersebut terlihat bahwa pola data konsisten sehingga data tersebut mengindikasikan adanya unsur musiman pada data. Selanjutnya, dengan menggunakan fungsi HoltWinters pada $\mathrm{R}$ maka diperoleh nilai parameter pemulusan untuk alpha, beta, gamma dan seasonal pada persamaan (4) dapat yang dapat dilihat pada Tabel 2.

Tabel 2. Estimasi parameter model seleksi ARIMA pada data latih dengan taraf kepercayaan $95 \%$

\begin{tabular}{cc}
\hline Parameter & Nilai \\
\hline$\alpha$ & 0,8237827 \\
$\beta$ & 0,0403956 \\
$\gamma$ & 1,0000000 \\
\hline
\end{tabular}

Nilai parameter penghalus tersebut tersebut diambil dari nilai rentang terkecil dari luaran $R$ yang ditampilkan dengan melihat error terkecil.

$>$ databaru $<-t s($ gdp_growth, start=1, frequency=3)

$>$ components_databaru $<-$ decompose(databaru)

$>$ plot(components_databaru)

$>$ HW1 <- HoltWinters(databaru)

$>$ HW2 <- HoltWinters (databaru, alpha=0.2, beta=0.1, gamma=0.1)

$>$ HW2 for $<-$ forecast $(H W 2, h=4$, level $=c(80,95))$

$>$ plot $(H W 2$ for, $x \lim =c(1,30))$

$>$ lines(HW2_for\$fitted, lty=2, col="purple")

Untuk menentukan apakah parameter pemulusan yang diperoleh telah fit pada data latih yang digunakan maka digunakan parameter pemulusan pembanding yakni model tipe Holt-Winters dengan nilai estimasi $\alpha=0,2, \beta=0,1$ dan $\gamma=0,1$. Hasil perbandingan fit 
data pada model Holt-Winters dapat dilihat pada Gambar 5.

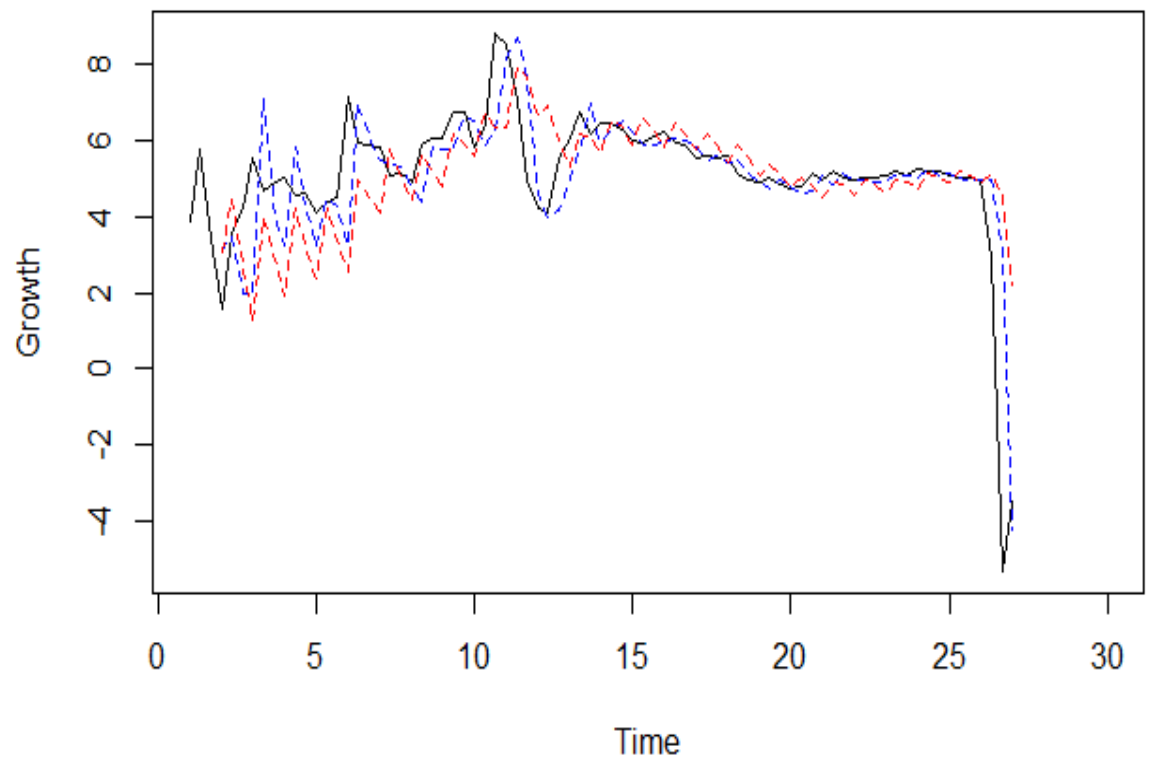

Gambar 5. Fit data menggunakan Holt-Winters model tipe I (garis biru: $\alpha=$ $0,8237827, \beta=0,0403956$ dan $\gamma=1$ ) dan model tipe II (garis merah: $\alpha=0,2, \beta=0,1$ dan $\gamma=0,1)$

Perbedaan kedua model dapat dilihat pada Gambar 4. Model dengan parameter pemulusan pada Tipe I lebih fit pada data pertumbuhan ekonomi dibandingkan dengan menggunakan parameter pemulusan pembanding sehingga model Tipe I yang digunakan untuk melakukan tahapan peramalan. Peramalan model Tipe I dapat dilihat pada Gambar 6.

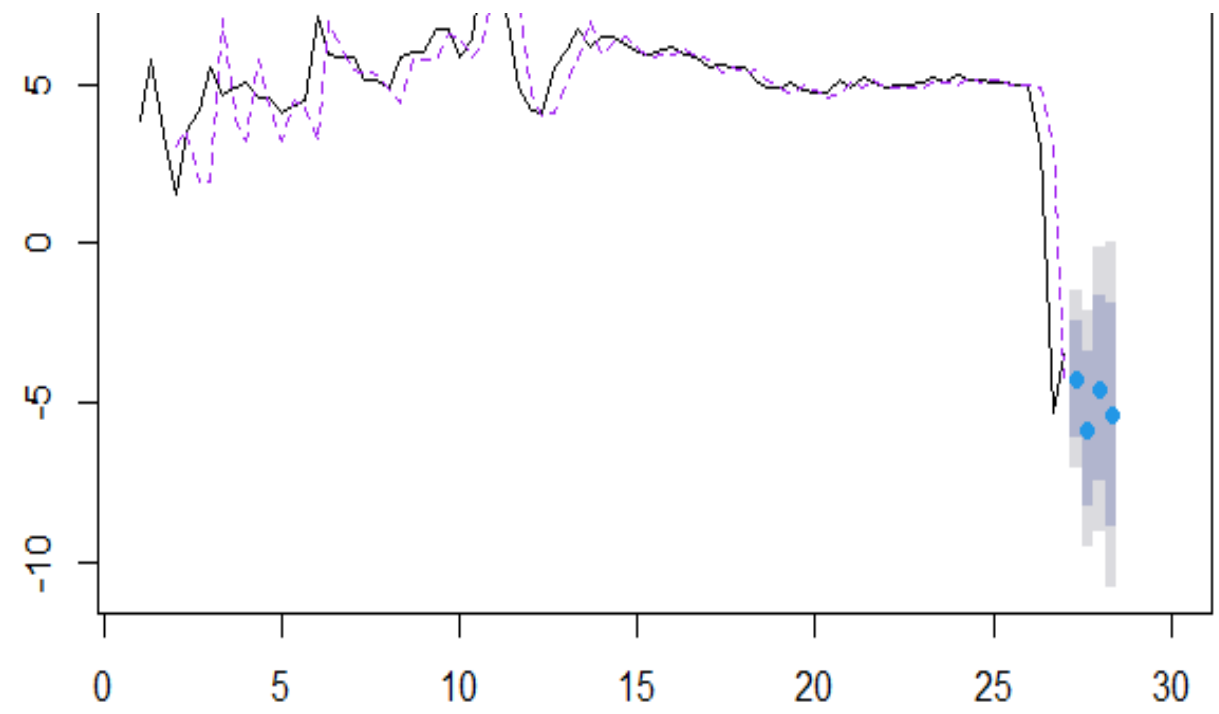

Gambar 6. Peramalan Model Tipe I Holt-Winters pada Data Pertumbuhan Ekonomi

Gambar 6 menjelaskan bahwa hasil peramalan kuartal pertumbuhan ekonomi 


\section{A. Asrirawan, et.al}

Indonesia dan derah batas bawah (lower) dan batas atas (upper). Meskipun hasil peramalan menunjukkan adanya peningkatan pertumbuhan ekonomi Indonesia empat data kuartal ke depan akan tetapi nilai tersebut masih berfluktuasi di sekitar daerah sumbu negatif. Oleh karena itu, pertumbuhan ekonomi Indonesia diprediksi bahwa masih akan mengalami resesi dengan menggunakan model Holt-Winters.

\subsection{Model Dynamic Linear Pertumbuhan Ekonomi Indonesia}

Pemodelan data pertumbuhan ekonomi menggunakan model dynamic linear dapat dilakukan di $R$ dengan memakai library $\mathrm{dlm}$. Adapun kode source untuk model tersebut dimulai dari membangun function dengan menggunakan 3 parameter.

model.build $<-$ function $(p)\{$

return(

$d \operatorname{lmModPoly}(2, d V=p[1], d W=p[2: 3]))$

Hasil estimasi parameter model dynamic linear dengan menggunakan fungsi dlmMLE berturut-turut adalah $-0,0065 ; 1,5767 ; 0 ; 1,00174$ dan 1 sehingga jika parameter tersebut diubah ke dalam bentuk matriks maka diperoleh hasil sebagai berikut:

$$
\begin{gathered}
F=\left[\begin{array}{ll}
1 & 0
\end{array}\right], V=[-0,00649], G=\left[\begin{array}{ll}
1 & 1 \\
0 & 1
\end{array}\right], \\
W=\left[\begin{array}{cc}
1,5767 & 0 \\
0 & 0,0074
\end{array}\right], m_{0}=\left[\begin{array}{ll}
0 & 0
\end{array}\right], c_{0}=\left[\begin{array}{cc}
0,000001 & 0 \\
0 & 0,000001
\end{array}\right] .
\end{gathered}
$$

Selanjutnya adalah melihat optimasi dari hasil estimasi parameter diatas dengan menggunakan proses penghalusan dari Kalman Filtering (fungsi dlmFilter dan

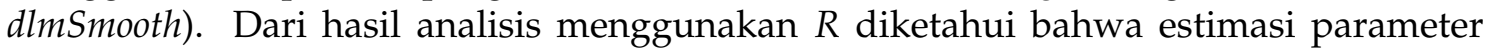
telah konvergen dengan nilai error kurang dari 0,0001 dan selanjutnya diperoleh nilai fit $a, c, m, R$, dan $f$ untuk semua data latih pertama sebagai berikut:

$$
\begin{gathered}
m=\left[\begin{array}{cc}
0 & 0 \\
3,87000 & 1,9349 \\
5,77000 & 1,9000 \\
\vdots & \vdots \\
-3,49846 & -0,2714
\end{array}\right], c=\left[\begin{array}{cc}
3162,7 & 3162,3 \\
0,0806 & 2236,06 \\
0,0804 & 1,26156 \\
\vdots & \vdots \\
0,0804 & 0,2321
\end{array}\right], \\
a=\left[\begin{array}{cc}
0 \\
0
\end{array}\right], R=\left[\begin{array}{cc}
5116,67 & 1954,39 \\
3162,27 & 0,8902 \\
2,04361 & 0,7776 \\
\vdots & \vdots \\
1,28042 & 0,23202
\end{array}\right],
\end{gathered}
$$


Pendekatan Univariate Time Series Modelling untuk Prediksi Kuartalan Pertumbuhan ...

$$
c=\left[\begin{array}{cc}
3162,7 & 3162,3 \\
0,0806 & 2236,06 \\
0,0804 & 1,26156 \\
\vdots & \vdots \\
0,0804 & 0,2321
\end{array}\right], f=\left[\begin{array}{c}
0 \\
5,80499 \\
7,67000 \\
\vdots \\
-5,62938
\end{array}\right]
$$

Hasil ramalan untuk data 80 sampai 83 atau 4 kuartal kedepan untuk nilai ramalan $a, \mathrm{c}$, $\mathrm{m}, \mathrm{R}$, dan $\mathrm{f}$ dapat dilihat pada matriks dan Gambar 7 .

$\hat{a}=\left[\begin{array}{ll}-3,769877 & -0,2714223 \\ -4,041300 & -0,2714223 \\ -4,312722 & -0,2714223 \\ -4,584144 & -0,2714223\end{array}\right], \hat{R}(1)=\left[\begin{array}{ll}1,63757 & 0.05411 \\ 0.05411 & 0.05564\end{array}\right], \hat{R}(2)=\left[\begin{array}{ll}3,37822 & 0.10976 \\ 0.10976 & 0.05739\end{array}\right]$

$\hat{R}(3)=\left[\begin{array}{ll}5,23190 & 0,16715 \\ 0,16715 & 0,05913\end{array}\right], \hat{R}(4)=\left[\begin{array}{ll}7,20212 & 0,22628 \\ 0,22628 & 0.05739\end{array}\right], \hat{f}=\left[\begin{array}{l}-3,76987 \\ -4,04130 \\ -4,31272 \\ -4,58414\end{array}\right]$

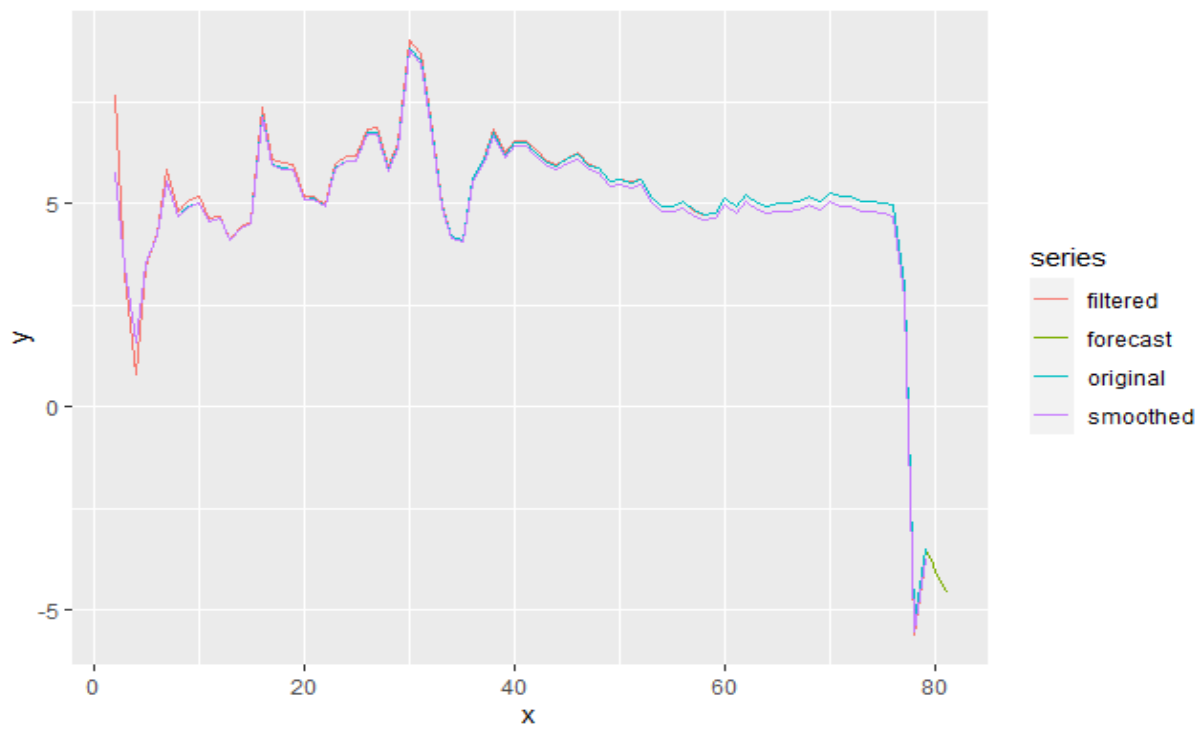

Gambar 7. Hasil peramalan model Dynamic Linear antara data aktual, filtered dan smoothed

Hasil fit dan peramalan model Dynamic Linear terlihat cukup baik dilihat pada Gambar 7. Jarak antara nilai data aktual (garis biru) dengan nilai ramalan cukup kecil bahkan nilai hasil pemulusan juga semakin mendekati nilai aktual. Namun, titik-titik peramalan model (garis hijau) tersebut di dua kuartal terakhir menunjukkan terjadinya pemurunan nilai pertumbuhan ekonomi Indonesia yang cukup signifikan atau semakin bertumbuh negatif (resesi). 


\section{A. Asrirawan, et.al}

\subsection{Kriteria Pemilihan Model Terbaik untuk Data Pertumbuhan}

Kriteria model univariat terbaik untuk memodelkan data pertumbuhan ekonomi secara kuartalan antara 2001-2021 kuartal pertama dilakukan perbandingan nilai MSE, MAE dan U-Theil. Hasil perbandingan ketiga kriteria antara data aktual dan prediksi atau peramalan dapat dilihat pada Tabel 3.

Tabel 3. Hasil Perbandingan Kriteria Kebaikan Prediksi dengan menggunakan MSE, MAE, dan U-Theil

\begin{tabular}{cccc}
\hline Model & MSE & MAE & U-Theil \\
\hline ARIMA & 0,765014 & 0,361830 & 0,156898 \\
Holt-Winters & 0,876899 & 0,468825 & 0,157140 \\
Dynamic Linear & 1,901297 & 1,917845 & 0,556128 \\
\hline
\end{tabular}

Model ARIMA memberikan nilai MSE, MAE dan U Theil yang paling kecil dibandingkan dengan model Holt-Winters dan dynamic Linear. Selisih nilai residual peramalan dari ketiga model tidak terlalu jauh khususnya jika menggunakan kriteria U-Theil. ARIMA dan Holt-Winters hanya mempunyai selisih 0,000242 sedangkan selisih model ARIMA dan Dynamic Linear sebesar 0,39923. Selain itu, perbandingan ketiga model juga disajikan dalam bentuk grafik dengan menggunakan library ggplot2 dan reshape pada Gambar 8.

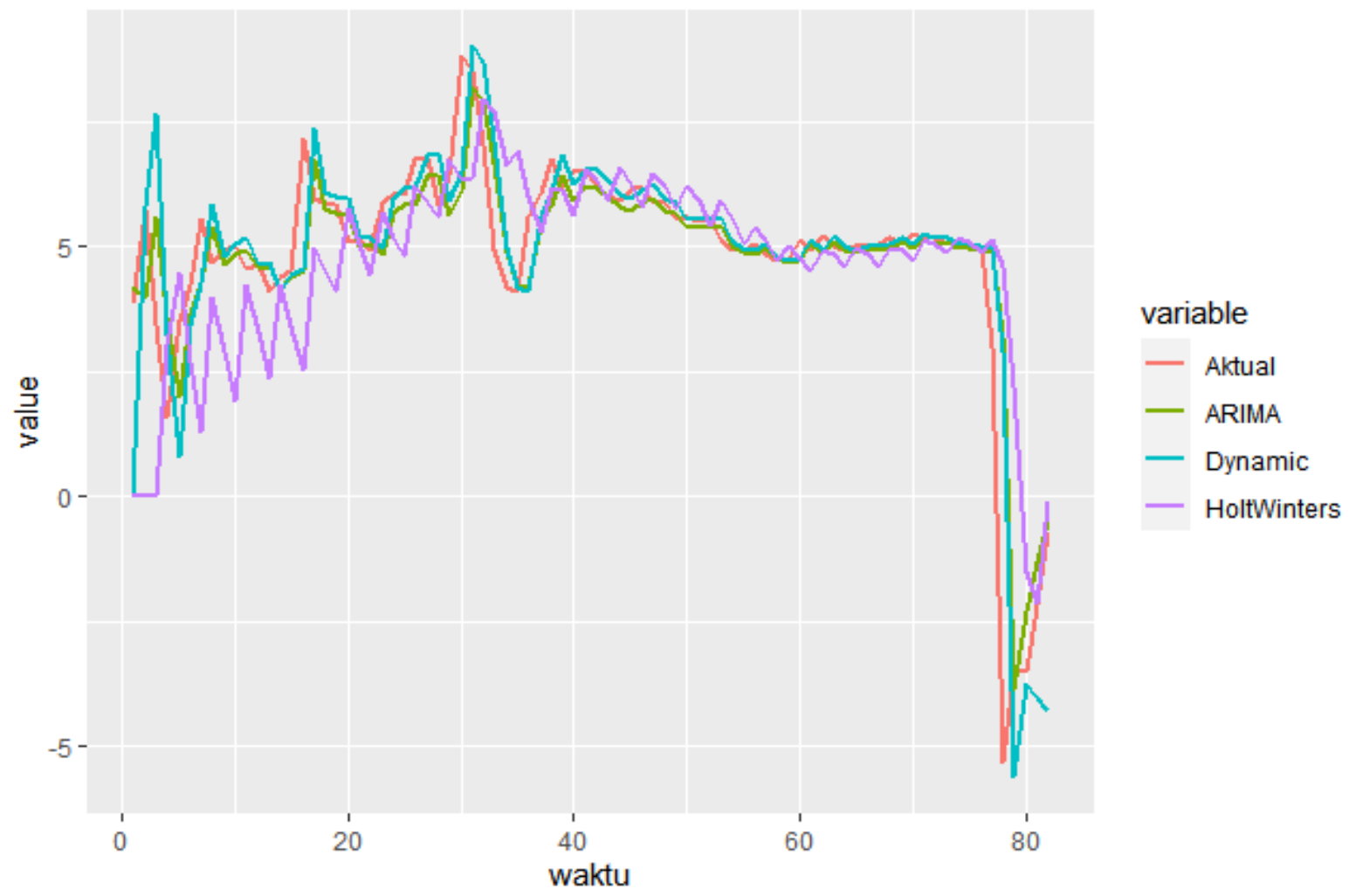

Gambar 8. Perbandingan fit dan peramalan model ARIMA, Holt-Winters dan Dynamic Linear

Gambar 8 menunjukkan bahwa grafik data pemodelan ARIMA, Holt-Winters dan Dynamic Linear mendekati grafik nilai data aktual (garis merah). Grafif Model ARIMA (garis hijau) terlihat lebih mendekati titik-titik pada data aktual dibandingkan dengan 
garis model-model yang lain.

\section{Kesimpulan}

Pemodelan data pertumbuhan ekonomi Indonesia secara kuartalan sangat cocok menggunakan model ARIMA $(1,0,0)$ yang memiliki unsur tren dan musiman berdasarkan kriteria nilai MSE, MAE dan U-Theil. Selisih nilai kriteria kebaikan model untuk ARIMA dan Holt-Winters terlihat cukup kecil hanya sekitar 0,000242 sedangkan selisih model ARIMA dan Dynamic Linear sebesar 0,39923. Selain itu, model Holt-Winters dan Dynamic Linear menghasilkan ramalan pertumbuhan ekonomi Indonesia masih mengalami resesi (bertumbuh negatif) pada empat data kuartalan selanjutnya, sedangkan model ARIMA menghasilkan ramalan pertumbuhan positif pada kuartal keempat.

\section{Ucapan Terima Kasih}

Ucapan terimakasih disampaikan kepada pihak Kementerian Keuangan dan Badan Pusat Statistik (BPS) Indonesia yang telah berkontribusi dalam penyediaan data pertumbuhan ekonomi secara kuartalan. Selain itu, Lembaga Penelitian dan Pengabdian Masyarakat dan Penjaminan Mutu (LPPM-PM) Universitas Sulawesi Barat yang telah bersedia memberikan bantuan dana penelitian untuk dosen pemula dari DIPA Unsulbar untuk pendanaan Tahun 2021.

\section{Referensi}

[1] BPS (Bapan Pusat Statistik), "Pertumbuhan Ekonomi Indonesia Triwulan IV-2020," Badan Pusat Statistik, Jakarta, Tech. Rep., 2021.

[2] Tradingeconomics.com, "Indonesia GDP Growth Rate 2018-2020."

[3] Kompas.com, "Tahapan Vaksin COVID-19 dan jadwal Pelaksanaannya," 2021.

[4] M. R. Abonazel and A. I. Abd-Elftah, "Forecasting Egyptian GDP using ARIMA models," Reports on Economics and Finance, vol. 5, no. 1, pp. 35-47, 2019, doi: http: //dx.doi.org/10.12988/ref.2019.81023.

[5] P. P. Piccoli, Identifification Of a Dynamic Linear Model For The American GDP. Italia: Edizioni Accademiche Italiane, 2017.

[6] L. Qadrini, A. Asrirawan, N. Mahmudah, M. Fahmuddin, and I. F. Amri, "Forecasting Bank Indonesia Currency Inflow and Outflow Using ARIMA, Time Series Regression (TSR), ARIMAX, and NN Approaches in Lampung," Jurnal Matematika, Statistika dan Komputasi, vol. 17, no. 2, pp. 166-177, dec 2020, doi: http:/ /dx.doi.org/10.20956/jmsk.v17i2.11803.

[7] A. Asrirawan, A. Seppewali, and N. Fitriyani, "Model Time Series untuk Prediksi Jumlah Kasus Infeksi Coronavirus (Covid-19) di Sulawesi Selatan," Jurnal MSA ( Matematika dan Statistika serta Aplikasinya), vol. 8, no. 2, p. 78, dec 2020, doi: http: //dx.doi.org/10.24252/msa.v8i2.17427.

[8] I. Al-Turaiki, F. Almutlaq, H. Alrasheed, and N. Alballa, "Empirical Evaluation of Alternative Time-Series Models for COVID-19 Forecasting in Saudi Arabia," International Journal of Environmental Research and Public Health, vol. 18, no. 16, p. 8660, aug 2021, doi: http://dx.doi.org/10.3390/ijerph18168660.

[9] C. C. Holt, "Forecasting seasonals and trends by exponentially weighted moving averages," International Journal of Forecasting, vol. 20, no. 1, pp. 5-10, jan 2004, doi: http://dx.doi.org/10.1016/j.ijforecast.2003.09.015.

[10] N. Nurhamidah, N. Nusyirwan, and A. Faisol, "Forecasting Seasonal Time Series Data using The Holt-Winters Exponential Smoothing Methode of Additive Models," Jurnal Matematika Integratif, vol. 16, no. 2, p. 151, dec 2020, doi: http:/ /dx.doi.org/10.24198/jmi.v16.n2.29293. 151-157. 


\section{A. Asrirawan, et.al}

[11] O. R. J. Hyndman and G. Athanasopoulus, Forecasting Principles and Practice, 2nd ed. Australia: OTexts, 2018.

[12] M. Laine, "Introduction to Dynamic Linear Models for Time Series Analysis," in Geodetic Time Series Analysis and Applications. Switzerland: Springer International Publishing, 2020, pp. 139-156, doi: http://dx.doi.org/10.1007/978-3-030-21718-1_4.

[13] G. Petris, "An R Package for Dynamic Linear Models," Journal of Statistical Software, vol. 36, no. 12, pp. 1-16, 2010, doi: http://dx.doi.org/10.18637/jss.v036.i12.

[14] R. J. Hyndman and A. B. Koehler, "Another look at measures of forecast accuracy," International Journal of Forecasting, vol. 22, no. 4, pp. 679-688, oct 2006, doi: http: //dx.doi.org/10.1016/j.ijforecast.2006.03.001.

[15] P. Silitonga, H. Himawan, and R. Damanik, "Forecasting Acceptance of New Students Using Double Exponential Smoothing Method," Journal of critical reviews, vol. 7, no. 01, pp. 300-305, jan 2020, doi: http://dx.doi.org/10.31838/jcr.07.01.57.

[16] H. Lee, "Data-Mining Bootstrap Procedure with Potential Predictors in Forecasting Models: Evidence from Eight Countries in the Asia-Pacific Stock Markets," East Asian Economic Review, vol. 23, no. 4, pp. 333-351, dec 2019, doi: http://dx.doi.org/10.11644/KIEP.EAER. 2019.23.4.366.

[17] Sunyoto, E. M. Hasanah, and Danang, Pengantar Ilmu Ekonomi Makro (Teori dan Soal). Yogyakarta: CAPS, 2014.

[18] P. Rahardja and M. Manurung, Teori Ekonomi Makro, 4th ed. Jakarta: Lembaga Penerbit Fakultas Ekonomi Indonesia, 2008.

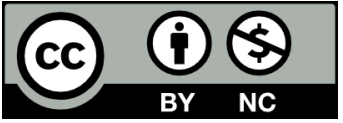

This article is an open-access article distributed under the terms and conditions of the Creative Commons Attribution-NonCommercial 4.0 International License. Editorial of JJoM: Department of Mathematics, Universitas Negeri Gorontalo, Jln. Prof. Dr. Ing. B.J. Habibie, Moutong, Tilongkabila, Kabupaten Bone Bolango, Provinsi Gorontalo 96119, Indonesia. 